\title{
3 Procedural justice in corrections
}

\author{
Julie Barkworth
}

\subsection{Introduction}

Prison provides an environment that exposes people to a range of physical and psychological conflicts, and prison staff are faced with managing these conflicts. Prisoners, particularly those who do not feel equipped to defend themselves, are likely to experience fear and anxiety as a result of increasing frustrations in an environment that is often overcrowded and where boredom is at a peak (Molleman \& Van Ginneken 2015; Sykes 1958; Toch 1997). Gresham Sykes' (1958) pioneering research on prison social life identified certain 'pains' experienced by prisoners that were considered acceptable and unavoidable consequences of imprisonment. The pains or deprivations identified by Sykes included the losses of liberty, heterosexual relationships, goods and services, autonomy, and security. In more recent times, with the introduction of visitation programmes, incentives and earned privileges schemes, and single-cell accommodation, ${ }^{1}$ some of the traditional pains of imprisonment have been reduced, but they remain present. With a changing prison environment also comes new pains. For example, Crewe (2011a) identified pains of uncertainty and indeterminacy, psychological assessment and self-government. Liebling, Arnold, and Straub (2011) identified pains relating to trust, fear, safety, re-making identity (for survival in prison and then for public acceptance upon release), humanity, relationships and fairness, power and security, hope, meaning making progress, and getting out of prison.

The primary goals of prison staff are to maintain a safe and secure prison environment, provide prisoners with 'care with humanity', provide opportunities for prisoners to address their offending behaviour, and to assist with the day-today operations of the prison (Liebling, Price, \& Bottoms 1999, p. 37). Staff are therefore able to help mitigate some of the pains of imprisonment previously identified through the way they perform their duties. However, meeting these goals within such a complex organisation and with prisoners who may have serious behavioural or psychological problems requires staff to be equipped with a range of skills and approaches for achieving successful outcomes. Procedural justice has recently been proposed as a method by which prison staff can meet these goals in their interactions with prisoners. Research undertaken in a range of regulatory contexts (e.g. taxation, policing, courts) has linked procedural justice

DOI: $10.4324 / 9780429317248-5$ 
with citizens' enhanced emotional well-being, quality of life, the degree to which they perceive authorities as legitimate, and their willingness to cooperate with authorities and comply with the rules and laws enforced by those authorities (e.g. Barkworth \& Murphy 2015, 2016; Jackson et al. 2012; Murphy \& Tyler 2008; Sunshine \& Tyler 2003; Tyler \& Huo 2002). However, only a limited number of studies have examined the relationship between procedural justice (or related concepts), prisoners' well-being, and compliance behaviour (e.g. Barkworth 2018; Beijersbergen et al. 2014, 2015, 2016; Brunton-Smith \& McCarthy 2016; Jenness \& Calavita 2018; Reisig \& Mesko 2009; Weinrath 2016). Considering the potential negative consequences the prison environment can have on prisoners, and the importance of staff-prisoner relationships for ameliorating the situation, finding ways to enhance these relationships is increasingly at the forefront of penology research. Research in the corrections context allows for a unique look at the importance of procedural justice, given that prisoners and prison staff interact on a daily basis, as opposed to the sporadic nature of interactions between authorities and citizens in non-correctional contexts.

This chapter provides an overview of the implications of procedural justice for prisoners' well-being and compliance-related behaviour. Section 3.2 presents an overview of the two key issues prisoners and prison staff are often faced with daily: prisoner well-being, which is often affected due to the nature of the prison environment, and prisoner compliance behaviour (including how staff may go about enforcing compliance). Section 3.3 provides an overview of Tyler's (1990) model of procedural justice, with consideration given as to how procedural justice might be utilised in interactions between prisoners and prison staff. Section 4 then introduces the empirical research conducted to date that examines the link between procedural justice, prisoners' well-being, and reduced psychological distress (see Section 3.4.1), between procedural justice and perceived legitimacy, cooperation, and compliance (see Section 3.4.2) and additional studies examining procedural justice in the context of prisoner grievance processes and in relation to interactions with offender supervisors (see Section 3.4.3). Section 3.5 highlights limitations of the research conducted to date and provides suggestions for future research directions before presenting conclusions in Section 3.6. Overall, the research demonstrates positive outcomes for prisoners and prison authorities when prison staff behave in a procedurally just manner.

\subsection{Two key issues in the prison environment: prisoner well-being and compliance}

Prisoners must undergo significant adjustments when entering prison in order to adapt to and cope with prison life. A significant body of research has shown that prisoners are at increased risk of experiencing depression, anxiety, and stress when compared to the general population (e.g. Gullone, Jones, \& Cummins 2000; Schneider et al. 2011). These risks can be attributed to their experiences of the quality of prison life as a result of reduced activity, support, feelings of safety, and visits from family and friends (Toch 1997; Wooldredge 1999). 
As a result of heightened levels of anxiety, fear, and depression, prisoners are also more likely to experience suicide ideation, with suicide rates among this population higher than in the general population (Fazel, Grann, Kling, \& Hawton 2011, p. 193). How staff interact with and respond to prisoners may subsequently influence the way prisoners react. Staff-prisoner relationships are arguably at 'the heart of prison work' (Liebling \& Price 2001, p. 75). Therefore, staff can ultimately act as a protective factor against prisoner distress and suicidal ideation (Daniel 2006). The respect, fairness, and humanity shown in positive staff-prisoner relationships have been linked with lower levels of stress and improved quality of life and prisoner well-being (Liebling 2011; Liebling, assisted by Arnold 2004; Molleman \& Van Ginneken 2015; Slotboom, Kruttshnitt, Bijleveld, \& Menting 2011).

In addition to acting as a protective factor, what staff do and the way in which they do it can have important implications for the type of order they establish and the chances of successfully implementing the right type of order (Sparks, Bottoms, \& Hay 1996). Order within prisons is clearly important for maintaining a safe and secure environment for both prisoners and staff. Prison staff are greatly outnumbered by prisoners in any correctional facility, indicating that prisoners could overpower staff if they chose to do so (Cressey 1961). As a result, prison provides an environment where force is more likely to be used to enforce rules and regain control. However, the use of excessive force may lead to detrimental psychological consequences for prisoners, or result in increased acts of rulebreaking, resistance, and retribution, particularly by those who already do not view the regime as legitimate (Jackson, Tyler, Bradford, Taylor, \& Shiner 2010, p. 5). Jackson et al. (2010, p. 5) therefore suggest that it may be even more important in the prison environment than elsewhere to find alternatives to the use of coercive power and excessive force, particularly for encouraging voluntary cooperation with staff and willing compliance with prison rules. Given that procedural justice has produced a number of positive outcomes regarding well-being and compliance when examined in a range of regulatory contexts (as outlined in Section 3.1), scholars have more recently begun to consider the potential benefits of procedural justice in the context of prison staff interactions with prisoners.

\subsection{What is procedural justice and what might it look like in prison?}

Procedural justice is commonly understood as the perceived fairness of the treatment received and the perceived fairness of procedures used during a decisionmaking process (Blader \& Tyler 2003, p. 748). Early procedural justice scholars (e.g. Thibaut \& Walker 1975) examined third-party disputes and argued that people placed greater importance on receiving a favourable outcome and what they needed to do to achieve that outcome than on the treatment they received; that is, they were motivated by instrumental concerns. According to Thibaut and Walker (1975) procedural justice is important to people because it allows them to take control of the decision-making process and therefore have influence over the 
outcome of this process. Tyler (1990), however, argues that people are more concerned with how they feel they are being treated rather than with outcomes; that is, they are motivated by relational concerns. Tyler argues that procedural justice matters because it communicates to people that they are valued and respected by those in authority, and subsequently their self-worth is strengthened. Tyler's model of procedural justice incorporates four key elements of respect, neutrality, voice and trustworthiness.

Respectful treatment involves treating people with respect, dignity, and politeness (Tyler \& Lind 1992, p. 141). Pilling (1992, p. 6) has suggested that within a prison environment respectful treatment might be demonstrated by staff referring to prisoners by their preferred name, addressing them in a courteous manner, and asking them to do something rather than ordering them to do so. ${ }^{3}$ In contrast, disrespectful treatment might involve referring to prisoners by numbers, not acknowledging them as they pass by, or not making an effort to get to know them as individuals.

Neutrality refers to making decisions using a consistent set of rules and procedures, rather than basing decisions on personal opinions or prejudices (Tyler \& Fagan 2008 , p. 239). Tyler (2010, p. 130) argues that there are ample opportunities within a prison environment for decisions to be made based on personal prejudice given the nature of those being governed; however, he also acknowledges this is an environment with specifically defined rules upon which authorities can base and explain their decisions. In general, neutrality within the prison environment is important for the consistent and fair application of rules to all prisoners, and for clearly justifying and explaining exceptions to those rules when discretion is utilised.

Voice allows individuals an opportunity to explain their side of the story before a decision is made (Tyler 2010, pp. 129-130). For prisoners, this means being given an opportunity to state their case when a conflict has arisen and having an opportunity to participate in both formal and informal processes that allow prisoners to contribute to decisions made about their time spent in incarceration (Tyler 2010, p. 129). Crewe (201la, p. 514) highlights the fact that prisoners are often frustrated at not being given an opportunity to contribute to decisions about categorisation or release, and this can subsequently result in them feeling they are not being treated with the respect due to them as a person.

Finally, trustworthiness refers to an authority communicating to the individuals they govern that they are acting in their best interests and that they are open and honest in their interactions (Tyler 2007, p. 31). When people perceive authority as trustworthy, they are more willing to conform to the group norms that authority represents (Boeckmann \& Tyler 2002, p. 2071). Prison staff may be able to display trustworthiness by expressing a genuine interest in prisoners' well-being, recognising signs of potential psychological struggles, and checking in with them to see how they are doing. Liebling and Price (2001) noted that prison staff are often hesitant to completely trust prisoners and struggle with the conflict of demonstrating care while maintaining security and order; however, 
when staff can maintain a balance between these roles, they are more likely to maintain positive and trustworthy relationships with prisoners.

Liebling and Arnold (2004) spent considerable time in prisons to identify what makes some prisons better than others at providing a safe and secure environment, focusing on what works best rather than what does not work. They suggested that prison quality had not been previously satisfactorily defined in official measures of the prison, arguing that an important aspect of prison quality is the concept of moral performance and that 'prisons should perform well because it is important to treat human beings well' (p. 473). Liebling and Arnold's study of 'what matters' in prison identified that the moral performance of a prison refers to 'those aspects of a prisoner's mainly interpersonal and material treatment that render a term of imprisonment more or less dehumanising and/or painful' (p. 473). What mattered to prisoners were positive staff-prisoner relationships. This includes staff who treated prisoners with respect, humanity, and fairness, and staff who improved safety and order within the prison. Therefore, when prison staff engage in procedurally just practices, such as treating prisoners with respect and dignity, being consistent in how decisions are made, giving prisoners a chance to state their case, and demonstrating concern and understanding, they are more likely to be seen as fair in their interactions with prisoners (Tyler 2010).

\subsection{Empirical research on prisoner perceptions of procedural justice}

Examining the concept of procedural fairness in corrections has emerged out of two bodies of research: the first from penology scholars (e.g. Liebling \& Arnold 2004; Sparks et al. 1996) and the second from procedural justice scholars (e.g. Barkworth 2018; Reisig \& Mesko 2009). Each body of research considers related concepts around fairness and respect while employing varying measures of each. The research from penology scholars has largely focused on Liebling and Arnold's (2004) study of prison quality and the importance of staff-prisoner relationships for building a healthy and well-functioning prison. As mentioned above, many of the concepts that arose out of Liebling and Arnold's study align with Tyler's (1990) model of procedural justice (e.g. respect, fairness, humanity). Tyler's model of procedural justice has been widely employed across many regulatory contexts, but there is only a small collection of recent studies that have specifically examined its importance in the corrections context. Each of the studies arising from these two bodies of research will be considered in the following sections.

\subsubsection{Well-being and psychological distress}

Liebling and Arnold's (2004) study of prison quality did not specifically examine procedural justice; however, it did identify a range of elements commonly considered part of procedural justice. Their study utilised an Appreciative Inquiry approach to determine 'what matters' to both prisoners and prison staff across 
five prisons in England and Wales. The findings of this approach were then used to develop a quality of life survey that was administered to 512 prisoners and 121 prison staff. The authors found that prisoners' perceptions of the quality of prison life were based on whether they viewed relationships with prison staff as positive. Prisoners who perceived staff were treating them with respect, humanity, and fairness, and who considered staff-prisoner relationships to be balanced, were also likely to indicate they had trust in prison staff and felt they were trusted by staff. This trust was the result of prisoner experiences with staff who were honest, responsible, and confident. Their study highlighted that positive staff-prisoner relationships were related to prisoner views of fairness and humanity, which in turn were related to enhanced prisoner well-being. A later study by Liebling (2011) found that diminutions in perceived respect, fairness, and humanity in staff-prisoner interactions were subsequently associated with heightened levels of stress related to prisoner suicide rates.

Similarly, Slotboom et al. (2011) administered a survey to 251 female Dutch prisoners to examine links between staff treatment and prisoners' psychological distress. Prisoners who felt they were treated disrespectfully reported more depressive symptoms, irritability, post-traumatic stress disorders, and thoughts of self-harm. These studies indicate the importance of the procedural justice element of respectful treatment for reducing prisoners' psychological distress.

Researchers from the Netherlands carried out a longitudinal study from 2010 to 2011 , which sought to examine the importance of procedural justice for prisoner well-being (Beijersbergen et al. 2014). A self-report survey was administered to a total of 824 prisoners who had been in pre-trial detention for three weeks. The survey was then administered again after three months. Elements of procedural justice as measured by Liebling and Arnold (2004) were used by Beijersbergen et al. (2014). They included fairness, respect, humanity, and relationships with prison staff (similar sub-scales were also used by Mol \& Henneken-Hordijk 2008). ${ }^{4}$ Prisoner mental health was assessed with a psychometric assessment. Prisoners who reported positive perceptions of procedural justice after three weeks in custody also reported fewer mental health problems three months later (Beijersbergen et al. 2014). While both Liebling and Arnold (2004) and Beijersbergen et al. (2014) referred to Tyler's (1990) model of procedural justice in their respective studies, neither indicated the measures were specifically derived from Tyler's work.

Barkworth (2018) was the first to specifically apply Tyler's four-factor model of procedural justice in a study considering prisoners' well-being and psychological distress. Procedural justice was therefore measured as respect, trustworthiness, neutrality, and voice. Well-being was measured according to Liebling and Arnold's (2004) measure of well-being, which tapped into whether prisoners considered their experience of prison as painful or feeling like a punishment. Finally, psychological distress was measured using the Kessler-10 (k10) assessment tool. It assessed prisoners' self-reported depressive and anxiety symptoms. Key findings from Barkworth's study revealed that perceived procedural justice 
was positively related to higher levels of prisoner well-being and lower levels of psychological distress.

\subsubsection{Legitimacy, cooperation and compliance}

Several early prison studies also examined the relationship between procedural justice perceptions and legitimacy judgements, cooperation, and compliance. Across these studies, legitimacy tended to be measured in a variety of ways that assessed prisoners' feelings of obligation to obey prison staff, their trust in prison staff, and whether their morals and values aligned with prison staff. When staff, who act as representatives of the institution, are perceived as legitimate, so too is the prison regime or the institution itself (e.g. Brunton-Smith \& McCarthy 2016, p. 9; Sparks \& Bottoms 1995). Sparks et al. (1996, p. 307) consider an authority's use of fair procedures as a 'representation dimension' of encounters and treatment and suggest that prisoners will comply with rules if they a) believe it is right and proper that a prison has rules and laws and b) that the prison officers enforcing those rules are fair in their means of exercising power and therefore can command authority. Hence, prisoners who perceive prison staff and the prison regime to be legitimate also believe the prison should have rules, and those rules should be followed.

Early studies considered the link between fair treatment and legitimacy and between fair treatment, legitimacy, and compliance. For example, Ahmad (1996, cited in Liebling \& Arnold 2004) used structured interview data from 230 prisoners in the UK to examine the fairness of prison life. Prisoners indicated that interpersonal aspects of fairness, such as being treated with respect by staff, and being treated with understanding, concern, and equality, were most important to prisoners. Ahmad also found that prisoner perceptions of staff fairness were also related to regime fairness, which can be linked to views of legitimacy. Butler and Maruna (2009) further found that prisoners were more likely to feel victimised by an authority and were less likely to take responsibility for their actions when they felt treated with disrespect.

Perhaps most notable is the work of Sparks et al. (1996), who conducted extensive fieldwork in two maximum-security prisons in the UK (Long Lartin and Albany). Over six weeks, Sparks and colleagues observed daily routines, engaged in informal discussions with prisoners and staff, and conducted interviews with 83 prisoners and 66 staff. Official data regarding prisoner population characteristics and recorded incidents was also utilised. Long Lartin was viewed as a more relaxed prison with less reported staff-prisoner conflict, and was therefore seen as the more legitimate of the two prisons examined. The relaxed environment of Long Lartin was generally attributed to steps taken to improve the loss of autonomy (e.g. prisoners allowed to wear their own clothes rather than a uniform) and loss of liberty (e.g. more freedom to move around corridors at certain times). Prisoners indicated that good staff were those who helped them, did not promise something they could not deliver, had a sense of humour, and were 
not antagonistic. It was found that prisoners had particularly positive perceptions of staff who treated them with respect and decency. In general, the day-to-day actions of prison staff partially influenced the perceived fairness of those staff, with prisoners who viewed staff as fair also indicating they were more willing to comply with officer directives and prison rules. However, Long Lartin staff were seen to take a more flexible rather than consistent approach to order and control, which was a source of anxiety for some prisoners as they were uncertain as to how far they could go or what was expected of them. In the end, though, prisoners saw this as a 'mutually acceptable compromise' (p. 173). Based on key findings from their study, Sparks et al. highlighted the importance of legitimacy for encouraging compliance, and supported Woolf's (1991) argument that legitimacy can be achieved through prison staff behaving in a procedurally just manner.

In Slovenia, Hacin and Meško (2018) used qualitative interview data from 193 male and female prisoners to examine perceptions of fairness and staff legitimacy (e.g. prisoners' feelings of obligation to follow the rules and instructions imposed by prison staff and prisoners' acceptance of decisions made by prison staff even if they disagreed). They also studied differences between instrumental motives (e.g. avoiding punishment/receiving rewards) and normative motives (e.g. attitudes based on values and beliefs) for compliance. In general, prisoners felt prison staff were professional and treated them with respect but still felt obliged to obey staff and comply with rules even if they did not like how they were treated. Hacin and Meško argued:

Instrumental compliance is considered as the first step toward establishing legitimacy in a prison environment. It is unreasonable to expect that prisoners, who are defined by their fundamental conflict with the state, would internalise the norms of prison workers, whom they consider the direct representatives of the criminal justice system, immediately upon their arrival to prison.

They further claimed ' $[\mathrm{t}]$ he transition from prisoners' instrumental compliance to normative compliance is possible when relations between prison staff and prisoners are based on respect, legality, and fairness' (p. 16). This study provides further support for staff using procedural justice practices to encourage normative compliance, but indicates that additional research into understanding the various reasons why prisoners comply with prison rules should be conducted.

A range of studies considering prisoners' perceptions of the legitimacy of prison staff and compliance behaviour has also been developed out of Liebling and Arnold's (2004) prison quality work (e.g. Beijersbergen et al. 2015, 2016; Brunton-Smith \& McCarthy 2016). Liebling and Arnold, specifically found that perceived fairness of staff, prison rules, and decision-making influenced perceptions of order and control in prison, highlighting that staff-prisoner relationships and the idea of procedural justice are important for regulating the prison environment. 
As part of the Prison Project carried out in the Netherlands from 2010-2011, Beijersbergen et al. $(2015,2016)$ examined the link between procedural justice and prisoners' anger and misconduct (Study 1), and between procedural justice and prisoners' perceptions of legitimacy and likelihood of re-conviction (Study 2). Here, Beijersbergen et al.'s measure of procedural justice was created from four sub-scales relating to fairness, respect, humanity, and relationships with officers. In the first study, prisoner misconduct was measured using both self-report compliance data and official prison disciplinary reports (Beijersbergen et al. 2015). The results showed that prisoners who felt fairly treated three weeks into their time in detention were less likely to engage in misconduct three months later. The authors also confirmed that if prisoners received disciplinary action during the first three weeks of detention this had no impact on whether prisoners felt fairly treated by staff three months later. The study further showed that anger mediated the relationship between perceived procedural justice and subsequent misconduct; that is, those who felt unfairly treated by prison staff early in their detention were more likely to report feeling angry three months later and were therefore more likely to engage in misconduct. In the second study, Beijersbergen et al. (2016) utilised both survey and re-conviction data from 1,241 prisoners to examine the relationship between perceptions of procedural justice during their time in detention, the perceived legitimacy of the criminal justice system, and post-release offending behaviour. The study highlighted a significant link between positive perceptions of procedural justice and a reduced likelihood of re-conviction 18 months after release. Prisoners' perceptions of the legitimacy of the criminal justice system were not found to mediate this relationship. Overall, the findings from the Prison Project demonstrated that procedural justice (as per Liebling and Arnold's (2004) conceptualisation) is important for prisoners' behavioural outcomes, including misconduct within prison and likelihood of post-release offending.

Another study utilising Liebling and Arnold's (2004) measures was conducted by Brunton-Smith and McCarthy (2016) in England and Wales. Their study considered the role of both prison-level and individual-level characteristics to determine prisoners' perceptions of staff legitimacy. The legitimacy measure was taken at the individual level using data from the Surveying Prisoner Crime Reduction (SPCR) project, which included 3,000 prisoners sentenced to between one month and four years from 2005 to 2006 in England and Wales. Prisoners were surveyed within the first two to five weeks of entering prison and again within four weeks prior to release. The legitimacy measure covered prisoner perceptions of staff-prisoner relationships, trust (in staff and by staff), perceptions of fair treatment and support from staff, and perceptions of staff honesty and integrity. The procedural justice measure utilised data from the 2005 to 2009 round of the 'Measuring the Quality of Prison Life' (MQPL) survey (see Liebling, Hulley \& Crewe 2012 for further details of MQPL). An overall summary measure of procedural justice for each prison was utilised, which captured the fairness of the prison (e.g. consistent treatment from staff) and whether procedures were in place for prisoners to express their views during decision-making processes. The study did 
not measure individual prisoners' perceptions of procedural justice, but instead merged the individual-level measure of legitimacy and prison-level measure of procedural justice into one dataset. Brunton-Smith and McCarthy utilised multilevel modelling to demonstrate that when a prison was viewed as procedurally just, prisoners' perceptions of staff legitimacy were higher. In other words, those residing in prisons where the systems in place to respond to problems were seen to be clearer and fairer were more likely to perceive the prison as more legitimate (as per their views of staff legitimacy).

It should be noted here that the procedural justice and legitimacy measures used by Brunton-Smith and McCarthy are not typical of those used in similar research. For example, the legitimacy measure covered aspects around fair treatment, staff-prisoner relationships, humanity, and support that are often incorporated in measures of procedural justice; on the other hand, the procedural justice measure placed greater emphasis on procedures and privileges that are not often examined as part of common procedural justice measures. Interpreting the findings of this study should therefore be done with these variations in mind.

The studies discussed thus far demonstrated the importance of the perceived fairness of staff and prisons for improving prisoner perceptions of staff legitimacy and their willingness to comply with the prisons' rules. While these studies often refer to procedural justice in regard to measuring respect, fairness, and relationships; only a few recent studies have specifically incorporated Tyler's (1990) fourfactor model of procedural justice. For example, Weinrath (2016) conducted in-depth interviews with 38 prisoners and 24 correctional staff in four Western Canadian prisons to examine perceptions of procedural justice and legitimacy within staff-prisoner relationships. Weinrath found that when prisoners viewed staff behaviour as being consistent with the principles of procedural justice, they were more likely to perceive those staff as legitimate. In particular, prisoners felt that being treated with respect was the most important element of procedural justice. Weinrath's study identified the importance of procedural justice for improving staff-prisoner relationships and the perceived legitimacy of staff.

One of the first empirical studies to examine the relationship between prisoner perceptions of procedural justice, the perceived legitimacy of prison staff, and prisoner misconduct was conducted by Reisig and Mesko (2009) in a highsecurity Slovenian prison. They utilised self-report survey data collected in structured face-to-face interviews and official records from the six months following the interviews to capture both self-report and official measures of misconduct. Legitimacy was measured as a prisoner's sense of obligation to obey staff, and procedural justice incorporated the four key elements of respect, neutrality, voice, and trustworthiness. The results demonstrated that when prisoners viewed staff as more procedurally just, they were less likely to later engage in behavioural misconduct (the finding was supported with both self-report and official data). Interestingly, no relationship was found between perceptions of procedural justice and perceived legitimacy, or between legitimacy and prisoner misconduct. The findings from Reisig and Mesko's study suggest it is the perceived fairness of treatment that matters most for encouraging prisoner compliance. 
A recent study in Australia has also sought to empirically examine the effect of prisoner perceptions of procedural justice on the perceived legitimacy of staff (i.e. obligation to obey staff and accept staff decisions), on prisoners' cooperation, and on compliance behaviour (Barkworth 2018). Procedural justice captured Tyler's (1990) four key elements of respect, neutrality, voice, and trustworthiness. Legitimacy was measured as prisoners' sense of obligation to obey prison staff. Cooperation referred to prisoners' willingness to provide information to staff about the goings-on in prison. Compliance captured prisoners' willingness to follow the prison rules (self-report) and the number of breaches they had received (official data). It was found that prisoners who perceived staff as being procedurally just were more likely to also perceive them as legitimate and were more willing to cooperate with staff and comply with prison rules (supported with both self-report and official data).

Barkworth and Murphy (2019) further examined whether perceptions of procedural justice relate to prisoners' social distancing from staff and their subsequent compliance behaviour. Here, social distancing was operationalised using Braithwaite's (2003) motivational posturing styles that include commitment, capitulation, resistance, disengagement, and game-playing. The findings showed that prisoners who viewed staff as more procedurally just were more likely to subscribe to deferent postures of commitment and capitulation, and less likely to subscribe to defiant postures of resistance, disengagement, and game-playing. It was also found that those with deferent postures were more willing to comply with prison rules than those with defiant postures. These studies further support the positive implications for prisoners' behaviour through prison staff employing procedural justice practices.

The procedural justice perspective highlights the importance of normative compliance. Normative compliance occurs when people consider that rules and laws align with their own personal values, and when the authorities who enforce those rules and laws are seen as just and moral (Tyler 2007, p. 161). A particularly important factor for encouraging normative compliance is the perceived legitimacy of the authority charged with enforcing the rules and laws to be followed (Liebling \& Arnold 2004; Sparks et al. 1996; Tyler 1990). An authority is seen as legitimate when it is perceived as being entitled to make decisions and when people feel obligated to follow those decisions (Sunshine \& Tyler 2003; Tyler 1997). Legitimacy is considered most important for encouraging both cooperation and compliance behaviour because it is 'ethically more desirable, more cost-effective, and ultimately more durable than systems maintained "down the barrel of a gun"' (Jackson et al. 2010, p. 4). Sparks et al. (1996, p. 307) refer to the 'representational dimension' of people's encounters with criminal justice agencies: prisoners will comply partly because they believe a prison should have rules and laws, and partly because the staff enforcing those rules and laws are fair in how they exercise power and can therefore command authority.

Ultimately, procedural justice is important for building legitimacy and encouraging subsequent cooperation and compliance behaviour. Tyler (2003, p. 306) argues that when people view authorities as exercising power through 


\section{Julie Barkworth}

fair procedures, they are more likely to adopt the social values those authorities represent, which subsequently helps create and maintain a self-regulating and law-abiding society. Tyler and Blader $(2003$, p. 353) further argue that these social values represent what people feel they should do, and therefore 'reflect feelings of responsibility and obligation to follow group rules and the orders of group leaders'.

One of the key theoretical explanations for why procedural justice has a positive association with cooperation and compliance behaviour is Tyler and Blader's (2003) Group Engagement Model. The model is based on relational concerns and suggests that people's identification, or sense of belongingness, with a group is shaped through procedural justice. In this sense, people value being treated with respect and fairness and being given a voice as it communicates to them that they are valued and respected members of a group. Tyler and Blader (2003, p. 353) argue that 'Groups help to define who people are and help them to evaluate their status'. Hence, people feel good about themselves through associations with groups they perceive as having high status (Tyler \& Blader 2003). What should be considered in this context is whether prisoners attribute high status to prison staff and whether they are more likely to identify with prison staff rather than other prisoners. This is where using procedural justice practices may be particularly important; that is, prisoners may be more likely to perceive staff as having high status and may be more likely to identify with those staff when they perceive them to be procedurally just.

\subsubsection{Additional procedural justice studies}

Although not specifically examining prisoners' psychological and behavioural outcomes, it is important to mention additional research on procedural justice in the corrections context. For example, Jenness and Calavita (2018) compared prisoners' satisfaction with the process (procedural justice) and outcome (substantive justice) of grievances filed, for example, around staff misconduct, contesting a serious disciplinary violation or complaint about prison classification. Here, it was found that the outcome received was more important for prisoners' satisfaction than how the process was handled; that is, even those who considered the grievance to be adequately managed were unlikely to be satisfied with an unfavourable outcome. This particular finding opposes what is often found in the policing literature, that people can accept an unfavourable outcome if they believe that outcome has been arrived at through fair treatment and procedures (e.g. Tyler \& Huo 2002; Barkworth \& Murphy 2015). The authors did offer several explanations for their findings, including that prison is a high stakes environment and when the stakes are high it is more likely that perceptions of procedure and outcome will be combined (Heinz 1985 cited in Jenness \& Calavita 2018, p. 48). However, the findings do suggest that prisoners tend to place greater importance on instrumental concerns when an outcome has a direct impact on them. The conflicting findings from this study, compared to what is often found 
in the policing context, suggests that additional research into understanding prison grievance processes could be done.

Much of the research to date has focused on prisoner perceptions of interactions with correctional officers. However, a recent study by Bickers, Crewe, and Mitchell (2019) examined prisoner perceptions of procedural justice during interactions with offender supervisors (i.e. those responsible for risk assessments). It highlighted that staff involved in risk assessment were seen as unqualified to make such decisions and therefore lacked legitimacy (Crewe 2009, 2011b). Bickers et al. found that prisoner perceptions of procedural justice were low with regard to staff involved in risk assessment, which had negative impacts on developing positive relationships. Bickers et al. (2019, p. 17) argued that when staff prioritise actuarial risk assessments over developing quality relationships a range of negative outcomes is likely, including disengaging from offender supervisors, withholding information, and bypassing formal management systems. They suggested that all staff working with prisoners should have a clear understanding of the key elements of procedural justice.

\subsection{Limitations of the current research and future directions}

This chapter has reviewed the research conducted to date on prisoner perceptions of procedural justice and subsequent psychological and behavioural outcomes. The research discussed in this chapter is not, however, without limitations. For example, there are variations in how procedural justice and legitimacy have been measured across different studies. On the one hand, several studies have utilised measures based on Liebling and Arnold's (2004) work on prison quality, incorporating elements of respect, fairness, humanity, and staff-prisoner relationships (e.g. Beijersbergen et al. 2014, 2015, 2016; Brunton-Smith \& McCarthy 2016). Others more specifically considered Tyler's (1990) model of procedural justice, examining the key elements of respect, trustworthiness, neutrality, and voice (e.g. Barkworth 2018; Reisig \& Mesko 2009; Weinrath 2016). Some measured legitimacy as felt obligation to obey prison staff (e.g. Barkworth 2018; Hacin \& Meško 2018; Reisig \& Mesko 2009), while others incorporated trust, fair treatment from staff, and perceptions of staff honesty and integrity in their measure of legitimacy (e.g. Brunton-Smith \& McCarthy 2016). Such differences in how both procedural justice and legitimacy have been measured means caution should be observed when considering the variations in findings across studies.

Most of the research has also only been conducted in high-security male prisons (e.g. Barkworth 2018; Beijersbergen et al. 2014, 2015, 2016; Liebling \& Arnold 2004; Reisig \& Mesko 2009; Sparks et al. 1996), and has largely been limited by the use of cross-sectional research designs, which only provide a snapshot of what is happening at one point in time. Cross-sectional research designs do not consider whether it is procedural justice that influences outcome variables (such as well-being, psychological distress, legitimacy, or cooperation and compliance) or 
whether prisoners have pre-existing mental health conditions, attitudes, or behavioural tendencies that influence their perceptions of procedural justice. Nagin and Telep $(2017$, p. 7 ) argue that perceptions of procedural justice and legitimacy are likely the result of a lifetime of influences based on culture, community, and family, rather than just one or more interactions with an authority. They further argue that it would be particularly difficult in disadvantaged communities to separate the influence of procedural justice on legitimacy and compliance from influences such as extreme poverty, racial isolation, and various forms of social dysfunction. Nagin and Telep $(2017$, p. 12) therefore argue that alternate common causes and reverse causality may be responsible for the links found between perceptions of procedural justice, perceived legitimacy, and compliance. In other words, those who are compliant to begin with are more likely to view an authority as procedurally just and legitimate, which then influences subsequent compliance behaviour. Beijersbergen et al. (2015) did, however, conduct a cross-lagged analysis and found that positive perceptions of procedural justice measured within three weeks of entering prison were related to fewer instances of misconduct three months later, although misconduct during the first three weeks of incarceration was not related to perceptions of procedural justice three months later. This study provides the first evidence from a corrections context that procedural justice influences compliance, but compliance does not influence perceptions of procedural justice. Longitudinal research designs are needed in order to determine any changes in prisoners' perceptions, conditions, attitudes, and behaviour that occur over time. Beijersbergen et al.'s $(2014,2015,2016)$ Prison Project is the only longitudinal study to examine perceptions of procedural justice on prisoners' mental health, misconduct behaviour, and likelihood of re-conviction after release. Their research, however, is limited by the fact that it only examined prisoners who had spent a maximum of three months in pre-trial detention, and therefore did not further consider the impacts that long-term incarceration may have on individuals.

Future research should further examine Tyler's (1990) model of procedural justice, as well as address methodological issues, including: the use of longitudinal designs; controlling for cultural, community and familial differences, and previous experiences with authorities; and evaluating an experimental manipulation of procedural justice. Future research should also consider perceptions of procedural justice from female prisoners, prisoners who have spent varying lengths of time in prison, those from medium, low, and work camp facilities, and those who have varying histories with engagement with criminal justice authorities. Finally, very little research has considered prison staff perspectives on procedural justice in corrections. Only a couple of studies have turned their attention to examining how prison staff perceive procedural justice and their willingness to use it (e.g. Lambert, Hogan, \& Barton-Bellessa 2011; Meško, Hacin, Tankebe, \& Fields 2017; Trammell et al. 2018). Additional research is needed to understand whether staff see value in using such practices; what barriers they may face in implementing procedural justice practices; and the potential risks they may associate with the use of such practices (e.g. whether it may make staff vulnerable to forming inappropriate relationships with prisoners). Given that prison staff are 
responsible for creating and maintaining positive relationships with prisoners that can enhance prisoner well-being and assist with keeping order, it is important to understand the role of procedural justice from their perspective.

\subsection{Conclusion}

Prison staff play an important role in creating a safe, secure, and well-functioning prison through improving prisoner psychological well-being and maintaining prison order. It is therefore vital for staff to find ways to ensure positive outcomes for prisoners, with procedural justice identified as a key way to achieve such a goal. This is important because the way in which staff treat prisoners can most easily be changed and implemented. The research reviewed in this chapter has shown that procedural justice can have positive outcomes for both prisoners and prisons. For example, procedural justice was related to enhanced prisoner wellbeing and reduced psychological distress. In addition, perceptions of procedural justice were related to the perceived legitimacy of prisons and prison staff, as well as an increased willingness to voluntarily cooperate with staff and comply with prison rules. While the research examining procedural justice in the corrections context has produced some promising findings, there is evidently much more research that can be undertaken in this area.

\section{Notes}

1 While single-cell accommodation has been introduced, over-crowding is still a consistent issue in prisons.

2 It should be noted that the correct referencing of this source is Liebling, assisted by Arnold 2004, as noted here; however, for ease of reading, this source will be cited as Liebling and Arnold 2004 from this point on.

3 It should be noted that prisons are hierarchical institutions and by their very nature may require staff to enforce prison rules through a range of methods including ordering prisoners to comply and using force when they do not comply. The suggestion to ask a prisoner to do something rather than ordering them to do so should be a first-step approach when circumstances do not require anything more authoritative or forceful (e.g. prisoner is going about their day-to-day activities and not causing any problems).

4 The study by Mol and Henneken-Hordijk (2008) has not been discussed as it was only published in Dutch.

\section{References}

Barkworth, J 2018, 'Prisons, procedural justice and motivational posturing: examining prisoners' well-being and compliance behaviour' (Unpublished doctoral dissertation), Griffith University, Brisbane, QLD.

Barkworth, J \& Murphy, K 2015, 'Procedural justice policing and citizen compliance behaviour: the importance of emotion', Psychology, Crime \& Law, vol. 21, no. 3, pp. 254-273. doi: 10.1080/1068316X.2014.951649

Barkworth, J \& Murphy, K 2016, 'System contact and procedural justice policing: improving quality of life outcomes for victims of crime', International Review of Victimology, vol. 22, no. 2, pp. 105-122. doi: 10.1177/0269758015627044 
Barkworth, J \& Murphy, K 2019, 'Procedural justice, posturing and defiant action: exploring prisoner reactions to prison authority', Justice Quarterly. Advanced online publication. doi: 10.1080/07418825.2019.1666905

Beijersbergen, KA, Dirkzwager, AJE, Eichelsheim, VI, Van der Laan, PH \& Nieuwbeerta, P 2014, 'Procedural justice and prisoners' mental health problems: a longitudinal study', Criminal Behaviour and Mental Health, vol. 24, no. 2, pp. 100-112. doi: 10.1002/cbm.1881

Beijersbergen, KA, Dirkzwager, AJE, Eichelsheim, VI, Van der Laan, PH \& Nieuwbeerta, P 2015, 'Procedural justice, anger, and prisoners' misconduct: a longitudinal study', Criminal Justice and Behaviour, vol. 42, no. 2, pp. 196-218. doi: $10.1177 / 0093854814550710$

Beijersbergen, KA, Dirkzwager, AJE \& Nieuwbeerta, P 2016, 'Reoffending after release: does procedural justice during imprisonment matter?', Criminal Justice and Behavior, vol. 43 , no. 1, pp. 63-82.

Bickers, I, Crewe, B \& Mitchell, RJ 2019, 'Offender supervision, prisoners and procedural justice', The Howard Journal, vol. 58, no. 4, pp. 1-19. doi: 10.1111/ hojo. 12343

Blader, SL \& Tyler, TR 2003, 'A four-component model of procedural justice: defining the meaning of a "fair" process', Personality and Social Psychology Bulletin, vol. 29 , no. 6 , pp. 747-758. doi: $10.1177 / 0146167203252811$

Boeckmann, RJ \& Tyler, TR 2002, 'Trust, respect, and the psychology of political engagement', Journal of Applied Social Psychology, vol. 32, no. 10, pp. 2067-2088.

Braithwaite, V 2003, 'Dancing with tax authorities: motivational postures and noncompliant actions', in V Braithwaite (ed.), Taxing democracy: understanding tax avoidance and evasion, Aldershot, Ashgate.

Brunton-Smith, I \& McCarthy, DJ 2016, 'Prison legitimacy and procedural fairness: a multi-level examination of prisoners in England and Wales', Justice Quarterly, vol. 33, no. 6, pp. 1029-1054. doi: 10.1080/07418825.2015.1023215

Butler, M \& Maruna, S 2009, 'The impact of disrespect on prisoners' aggression: outcomes of experimentally inducing violence-supportive cognitions', Psychology, Crime and Law, vol. 15, no. 2-3, pp. 235-250. doi: 10.1080/10683160802190970

Cressey, D (ed.) 1961, The prison: studies in institutional organizational change, Holt, Rinehart and Winston, New York.

Crewe, B 2009, The prisoner society: power, adaptation and social life in an English prison, Oxford University Press, Oxford.

Crewe, B 2011a, 'Depth, weight, tightness: revisiting the pains of imprisonment', Punishment and Society, vol. 13, no. 5, pp. 509-529. doi: 10.1177/1462474 511422172

Crewe, B 2011b, 'Soft power in prison: implications for staff-prisoner relationships, liberty and legitimacy, European Journal of Criminology, vol. 8, no. 6, pp. 455-468.

Daniel, AE 2006, 'Preventing suicide in prison: a collaborative responsibility of administrative, custodial, and clinical staff', The Journal of the American Academy of Psychiatry and the Law, vol. 34, no. 2, pp. 165-175.

Fazel, S, Grann, M, Kling, B \& Hawton, K 2011, 'Prison suicide in 12 countries: an ecological study of 861 suicides during 2003-2007', Social Psychiatry, vol. 46, pp. 191-195. doi: 10.1007/s00127-010-0184-4

Gullone, E, Jones, T \& Cummins, R 2000, 'Coping styles and prison experience as predictors of psychological well-being in male prisoners', Psychiatry, Psychology and Law, vol. 7, no. 2, pp. 170-181. doi: 10.1080/13218710009524983 
Hacin, R \& Meško, G 2018, 'Prisoners' perception of legitimacy of the prison staff: a qualitative study in Slovene prisons', International Journal of Offender Therapy and Comparative Criminology, vol. 62, no. 13, pp. 4332-4350. doi: $10.1177 / 0306624 X 18758896$

Jackson, J, Bradford, B, Hough, M, Myhill, A, Quinton, P \& Tyler, TR 2012, 'Why do people comply with the law?: legitimacy and the influence of legal institutions', British Journal of Criminology, vol. 52, no. 6, pp. 1051-1071.

Jackson, J, Tyler, TR, Bradford, B, Taylor, D \& Shiner, M 2010, 'Legitimacy and procedural justice in prisons', Prison Service Journal, vol. 191, pp. 4-10.

Jenness, V \& Calavita, K 2018, 'It depends on the outcome: prisoners, grievances, and perceptions of justice', Law \& Society Review, vol. 52, no. 1, pp. 41-71.

Lambert, EG, Hogan, NL \& Barton-Bellessa, SM 2011, 'The association between perceptions of distributive justice and procedural justice with support of treatment and support of punishment among correctional staff', Journal of Offender Rehabilitation, vol.50,no.4,pp. 202-220.doi: 10.1080/10509674.2011.552586

Liebling, A 2011, 'Moral performance, inhuman and degrading treatment, and prison pain', Punishment of Society, vol. 13, no. 5, pp. 530-550. doi: $10.1177 / 1462474511422159$

Liebling, A, assisted by Arnold, H 2004, Prisons and their moral performance: a study of values, quality, and prison life, Oxford University Press, Oxford.

Liebling, A, Arnold, H \& Straub, C 2011, An exploration of staff-prisoner relationships at HMP Whitemoor: 12 years on, Cambridge Institute of Criminology, Prison Research Centre, Cambridge.

Liebling, A, Hulley, S \& Crewe, B 2012, 'Conceptualising and measuring the quality of prison life', in D Gadd, S Karstedt \& SF Messner (eds), The SAGE handbook of criminological research methods, Sage, London.

Liebling, A \& Price, D 2001, The prison officer, Leyhill, Prison Service and Waterside Press.

Liebling, A, Price, D \& Bottoms, A 1999, An exploration of staff-prisoner relationships at HMP Whitemoor, Institute of Criminology, Cambridge.

Mesko, G, Hacin, R, Tankebe, J \& Fields, C 2017, 'Self-legitimacy, organisational commitment and commitment to fair treatment of prisoners: an empirical study of prison officers in Slovenia', European Journal of Crime, Criminal Law and Criminal Justice, vol. 25, pp. 11-30.

Mol, GD \& Henneken-Hordijk, I 2008, 'Gedetineerd in Nederland 2007', Een survey onder alle gedetineerden in het Nederlandse gevangeniswezen, Dienst Justitiele Inrichtingen, Den Haag. [Mol, GD \& Henneken-Hordijk, I 2008, Imprisonment in the Netherlands 2007. A survey among all prisoners in Dutch correctional facilities, The Hague, The Netherlands, Ministry of Security and Justice, National Agency of Correctional Institutions.]

Molleman, T \& Van Ginneken, EFJC 2015, 'A multi-level analysis of the relationship between cell sharing, staff-prisoner relationships, and prisoners' perceptions of prison quality', International Journal of Offender Therapy and Comparative Criminology, vol. 59, no. 10, pp. 1029-1046. doi: 10.1177/0306624X14525912

Murphy, K \& Tyler, T 2008, 'Procedural justice and compliance behaviour: the mediating role of emotions', European Journal of Social Psychology, vol. 38, pp. 652-668. doi: 10.1002/ejsp.502

Nagin, DS \& Telep, CW 2017, 'Procedural justice and legal compliance', Annual Review of Law and Social Science, vol. 13, pp. 5-28. 
Pilling, J 1992, 'Back to basics: relationships in the prison service', in Home Office (ed.), Perspectives on prison: a collection of views on prison life and running prisons, HMSO, London.

Reisig, MD \& Mesko, G 2009, 'Procedural justice, legitimacy and prisoner misconduct', Psychology, Crime \& Law, vol. 15, no. 1, pp. 41-59. doi: $10.1080 / 10683160802089768$

Schneider, K, Richters, J, Butler, T, Yap, L, Richards, A, Grant, L \& Smith, A 2011, 'Psychological distress and experience of sexual and physical assault among Australian prisoners', Criminal Behaviour and Mental Health, vol. 21, no. 5, pp. 333-349.

Slotboom, AM, Kruttschnitt, C, Bijleveld, C \& Menting, B 2011, 'Psychological wellbeing of incarcerated women in the Netherlands: importation or deprivation?', Punishment \& Society, vol. 13, no. 2, pp. 176-197.

Sparks, R \& Bottoms, A 1995, 'Legitimacy and order in prisons', The British Journal of Sociology, vol. 46, no. 1, pp. 45-62.

Sparks, R, Bottoms, A \& Hay, W 1996, Prisons and the problem of order, Clarendon, Oxford.

Sunshine, J \& Tyler, TR 2003, 'The role of procedural justice and legitimacy in shaping public support for policing', Law \& Society Review, vol. 37, no. 3, pp. 513-547.

Sykes, GM 1958, The society of captives, Princeton University Press, Princeton, NJ.

Thibaut, J \& Walker, L 1975, Procedural justice, Erlbaum, Mahwah, NJ.

Toch, H 1997, Corrections: a humanistic approach, Harrow and Heston, New York.

Trammell, R, Cook, AR, Marquez, MVD, Hinkle, P, Protze, LM \& Rodriguez, N 2018, 'From procedural justice to procedural injustice: understanding prison staff and inmate conflict', The Howard Journal, vol. 57, no. 4, pp. 537-555. doi: $10.1111 /$ hojo. 12285

Tyler, TR 1990/2006, Why people obey the law, Yale University Press, New Haven.

Tyler, TR 1997, 'The psychology of legitimacy: a relational perspective on voluntary deference to authorities', Personality and Social Psychology Review, vol. 1, no. 4, pp. 323-345. doi: $10.1207 /$ s15327957pspr0104_4

Tyler, TR 2003, 'Procedural justice, legitimacy, and the effective rule of law', Crime and Justice, vol. 30, pp. 283-357.

Tyler, TR 2007, 'Procedural justice and the courts', Court Review: The Journal of the American Judges Association, vol. 44, no. 1/2, pp. 26-31. Available at https://di gitalcommons.unl.edu/ajacourtreview/217

Tyler, TR 2010, 'Legitimacy in corrections: policy implications', Criminology \& Public Policy, vol. 9, no. 1, pp. 127-134.

Tyler, TR \& Blader, SL 2003, 'The group engagement model: procedural justice, social identity, and cooperative behavior', Personality and Social Psychology Review, vol. 7, no. 4, pp. 349-361.

Tyler, TR \& Fagan, J 2008, 'Legitimacy and cooperation: why do people help the police fight crime in their communities', Journal of Criminal Law and Criminology, vol. 6, pp. 231-275.

Tyler, TR \& Huo, YJ 2002, Trust in the law, Russell-Sage, New York.

Tyler, TR \& Lind, EA 1992, 'A relational model of authority in groups', Advances in Experimental Social Psychology, vol. 25, pp. 115-191. 
Weinrath, M 2016, Behind the walls: inmates and correctional officers on the state of Canadian prisons, University of British Columbia Press, Vancouver, Canada.

Wooldredge, JD 1999, 'Inmate experiences and psychological wellbeing', Criminal Justice and Behavior, vol. 26, no. 2, pp. 235-250. doi: $10.1177 / 0093854899026002005$

Woolf, Lord Justice 1991, Prison disturbances, April 1990, HMSO, London. 
$\because$ Taylor \& Francis

Taylor \& Francis Group

http://taylorandfrancis.com 